\title{
Notes
}

\section{NOTES TO INTRODUCTION}

I Grilagem is the illegal, private appropriation of land, typically using falsified documents. It remains a common practice in Brazil and played an important role in the urbanisation of São Paulo's periphery.

2 This heading invokes James Ferguson's (I999) eponymous book, which has been an inspiration to me.

3 www.seade.gov.br/produtos/midia/boletim-ped/rmsp/rmsp_anual_i9 97.pdf

4 www.seade.gov.br/produtos/midia/boletim-ped/rmsp/rmsp_set2oro. pdf

5 The 's' in 'state' is written in lowercase in order to reinforce the differentiation sought here, in contrast to the more common use of 'State' merely representing a set of public institutions or ideological apparatuses. The notion is Weberian, as we refer to an objectified state: a human community that successfully imposes a legitimate monopoly of forces on a particular territory (Weber, I967). However, state is also an agent and, like all agents, it is produced during and as a result of its actions. The theory that substantiates this objective and ordered definition of state in Weber is a theory of action. Abrams (2006) warned of the difficulty imposed by the study of the state, precisely because it implies studying under the perspective of the Simmelian theory of objectification (state as idea, state as system). Vianna (2014) and Souza Lima (2002) have demonstrated how it is more productive to understand what are known as state processes in motion, observing its will to be progressive and its instances of reification. Das and Poole (2004) have demonstrated that there is no state centre and that operations of legitimisation and constructing legibility are fundamental to its validation in legal terms.

6 'Or depuis cinquante ans, les travaux convergent pour montrer qu'il ne suffit pas d'une loi ou d'une annonce pour modifier les comportements. 


\section{Notes}

Les exemples abondent de décisions répétitives qui restent de peu d'effet et manifestent plutôt l'impuissance de l'État. [end note] L'exemple le plus ancien est la cascade d'édits royaux sur la répression du vagabondage qui ne purent empêcher l'émigration rurale et une forte circulation des populations du XIVe au XIXe siècle. Au XXe la question des personnes sans domicile fixe n'a cessé d'augmenter' (Lascoumes and Le Galès, 20I2, p. I8).

7 Brazilian middle classes and elites are very heterogeneous but could not be described by the 'globalised mind' found in Europe by Andreotti, Le Galès and Moreno-Fuentes (2015).

8 I have chosen to continue using the term 'peripheries', despite recognising their problems (especially the implication of a watertight division between 'centre' and 'periphery' and, depending on the context, a range of associated social stigmas). I made this choice, above all, because it strikes me as the most intelligible category for highlighting the set of social dynamics to which I refer throughout this book. 'Urban poor', 'working' or 'popular classes', 'low income sectors' or related concepts seemed less effective, in relative terms, when switching between ethnographic description and analysis of the structure of public debates. When I speak of the "peripheries' of São Paulo, therefore, I refer to environments situated in time and space, in which real people relate to one another and to other spheres of the social world in ways that are plural and heterogeneous. On the other hand, and at the same time, the term 'peripheries' helps us to recognise the regularities that are reproduced in these regions of the city and which demand significant analytical investment.

\section{Notes to Chapter 1}

I In Brazil's racial identity's puzzle most Italians, as well as Arabs or Jews, are considered to be white, despite the fact that this is different in many other national and regional ethnic-racial puzzles.

2 It would be from lived experience rather than abstract explanation that categorical meanings would emerge. Inspiration for this debate stems from Rancière (2002) and Wittgenstein (2009) (particularly paragraphs 98-Io6).

3 'On the one hand, it is clear that every sentence in our language is "in order as it is". That is to say, we are not striving after an ideal, as if our ordinary vague sentences had not yet got a quite unexceptional sense, and a perfect language awaited construction by us. On the other hand, it seems clear that where there is sense there must be perfect order. So there must be perfect order even in the vaguest sentence' (Wittgenstein, 2009, paragraph 98, p. 44). The debate would be a lengthy one, sparked by that between Durkheim and William James, before being taken up by 


\section{Notes}

pragmatists and interactionists. For a new approach to the debate, see Werneck (2012).

4 For a debate on routine as structure, see Machado da Silva (2008). Das (1995, 2006a and 2012), performs in-depth studies on the relevance of everyday life in the construction of meaning, as do Bayat (2013) and Blokland, Giustozzi and Schilling (2016).

5 I sought to address the problem of difference, particularly in terms of the public and emic notions of 'periphery' in Feltran (2013, 2014).

6 Author Laura Moutinho (2006) analyses the life stories of three poor black men in Rio de Janeiro, stating in an introductory summary that 'homophobia overlaps with racism' (Moutinho, 2006, p. II2) in her characters' broader negotiation of difference. Moutinho also gives authorial clues as to how one category of difference is objectified in a more central fashion than others in the defining of situations, without implying that the other categories are not simultaneously and mutually objectified. For an excellent review of the debate on intersectionalities, see Piscitelli (2008) or Cho, Crenshaw and McCall (2013).

7 Aesthetic and politics are also considered here in terms of a concept proposed by Jacques Rancière (2005, p. I8): 'Such forms are revealed to be tied to a certain political regime related to indeterminate identities, the delegitimation of words' positions, of the deregulating of the sharing of space and time. Such an aesthetic political regime befits democracy, the regime of assemblies of craftspeople, intangible written laws and the theatrical institution.'

8 Categorical judgements of value may therefore be constructed even if they are not immediately objectified into words and action. The life of categories is processed at every moment in the flux of experience, albeit silently (Das, I999). In theoretically suggesting a reflection very similar to that of the present text, even reflecting on aesthetics and intersectional politics, Lowenkron (2015) notes how federal police treated a 'male' transvestite with respect while working, rendering her a target for jokes and insults outside of their professional interaction.

9 Notes on a scene from everyday life observed in January 2017 in São Carlos, São Paulo state, Brazil.

Io Available at www.youtube.com/watch?v=AgJdeavBa8g (accessed I March 2017). The scene lasts a little over seven minutes, and is fully transcribed here.

II Laura Moutinho resumes the debate on the 'Mediterranean model' of 'honour and shame' in which, 'while men enjoy wide sexual permissiveness, women are controlled by a rigid sexual set of morals, whose righteousness serves as the custodian of male honour: shame falls on women and it is the male control that maintains family honour' (Moutinho, 2006, p. I00). 


\section{Notes}

I2 Simmel discusses this division among women in Europe at the beginning of the twentieth century by means of a study on prostitution, proclaiming: 'as long as marriage exists, so will prostitution' (Simmel, 2006, p. Io).

I3 http://gi.globo.com/sao-paulo/noticia/20i6/o3/policia-matou-duaspessoas-por-dia-nos-2-primeiros-meses-de-2016-em-sp.html (accessed 3I March 2016).

I4 For an excellent debate on the human status as community-based and political, see Arendt, (195I) or Cavell, (2006).

I5 'The adjective 'authoritarian' and the noun 'authoritarianism' are specifically employed in three contexts: the structure of political systems, the psychological devices related to power and political ideologies. In the typology of political systems, regimes privileging governmental authority are known as authoritarian, diminishing the consensus in a relatively radical fashion, concentrating political power in the hands of a single person or in a single body and placing representative institutions in second place. (...) In a psychological sense, an authoritarian personality is used to refer to a personality type formed by various characteristic traits centred on the coupling of two strictly linked attitudes: on the one hand, a concerned obedience towards superiors, sometimes including favours and adulation for all those retaining strength and power; and on the other hand, an arrogant and condescending treatment of hierarchical inferiors and anyone who does not have power and authority. (...) Authoritarian ideologies are therefore ideologies that negate equality among men in a relatively decisive manner, focusing on the hierarchical principle as well as arguing in favour of authoritarian regimes and often exalting some of the components of the authoritarian personality as virtues' (Bobbio, Matteucci and Pasquino, I998, p. 94).

\section{Notes to Chapter 2}

I This first interview with Pedro was carried out by myself and Ana Paula Galdeano Cruz, whom I thank. Thanks also to Alexandre Werneck for the comments on the first draft of the chapter.

2 Pedro says his cousin was executed after a 'debate'. The following chapter discusses the reinforcement of these debates during the expansion of the PCC in São Paulo.

3 'Sign the LA' means to attend Casa Foundation (the former FEBEM) on a monthly basis, where their Community Service is monitored in accordance with judicial decision.

4 Pedro's brother wasn't involved with the 'crime' at this time, but did become so again when he was older. He was in prison at the time of this first interview, having been caught during a robbery he carried out in the centre of São Paulo. 


\section{Notes}

5 Semi-release is an intermediate socio-educational measure between Assisted Freedom and Internment, which is similar to the semi-open regime for adults.

6 The fatal results of these trajectories are often highlighted in this literature. In São Paulo the homicide rate among adolescents and young people remains high, even if it has fallen significantly in recent years. The average number of homicides in the capital, which had been around 30 per 100,000 by the end of the i99os, dropped steadily from 2000 onwards. Average rates in the Sapopemba district also declined steadily, from 209 in 2000 to $5 \mathrm{I}$ in 2007 (PRO-AIM, 2008), remaining stable from then onwards (Santos Silva, 2014; Ruotti et al., 2017).

\section{Notes to Chapter 3}

In 2019 the ages of Ivete and her children were: Ivete (6I); Ivonete (43); Marcela (42); Anísio (30†); Raúl (39); Neto (36); Alex and Lázaro (twins, $35)$; and Fernando (2I $\dagger)$.

2 In the programme Roda Viva, screened in October 2007 on the channel TV Cultura.

Durham (1973, chapter 8) discusses precisely this attempt to reproduce the patronage model in São Paulo, especially among families that, like Ivete's, were qualified to engage in only marginal jobs, without the protection of a contract or formal salary.

I study Marcela's trajectory in Feltran (2007). Rui (20I4) offers an indepth ethnography of this circuit.

'But I continue to be respected by them [the traffickers]. When I pass, they say hello, they know that I'm a person who won't give them any trouble, or mess with the police. On the contrary, if one comes running and says they need to hide, I'll hide them, because I can't do anything, I won't hand them in. Because they have their own lives, each one makes their choices, don't they?' (Ivete)

6 The new structure of the group implied that each one took responsibility for his or her own life. As the dynamics of cycles into and out of prison stabilised, Ivete stopped visiting the prisoners, and they stopped expecting visits.

\section{Notes to Chapter 4}

I In short, politics refers not only to disputes between already existing subjects on a pre-constituted terrain (the state, councils, civil society etc.) but, above all, to the dispute underlying the very institution of these terrains and subjects (Rancière, I996a, I996b), that is, the very definition of what is socially legitimate. 


\section{Notes}

2 That amounted to fifteen weeks without being able to work, since the usual work schedule for adolescents on the retail side of the traffic in Sapopemba is a rotation, in which each individual works one morning and one night per week.

3 This is a report shown on the channel Rede Record's 'Domingo Espetacular' ('Sunday Special') programme, available at: http://you tube.com/watch?v=XVs9yilXfZQ.

4 The expressions and names used in the report are maintained here. All the detained PCC members who participated in the conversations recorded by the police are identified as 'prisoner'.

5 'Checkmate' must end not only the life of the individual(s) sentenced, but the whole potential cycle of private revenge.

6 The average number of homicides in the capital, which reached around 30 per 100,000 by the end of the I990s, declined steadily from 2000 onwards. The average rate in the Sapopemba district, where I have conducted most of my fieldwork, declined by a factor of six between 200 I and 2008 in a steady way, falling from 60.9 per I0o,ooo in 2001 to only 8.8 per 100,000 in 2008. Source: author's calcuations based on data from PRO-AIM, City Council of São Paulo, January 20 ı.

7 Official data from the Secretaria de Administração Penitenciária (Ministry of Prison Administration) for the State of São Paulo show that the prison population rose from 55,000 in I994 to almost I90,000 in 20II. See www.sap.sp.gob.br. It is estimated that, on average, 5,800 people are released from São Paulo's prisons every month, compared to 6,600 entering. Meanwhile, there are 30,000 people who have been sentenced, but whom the prison system cannot accommodate. For a critique of the policy of mass incarceration, its motivations and consequences in the USA, the work of Wacquant (2009a, 2009b) is a key reference. Caldeira (2009) goes beyond criticising the author's argument.

8 Mano Brown (2009), available at www.youtube.com/watch? $\mathrm{v}=\mathrm{PQ}_{4} \mathrm{dP}$ 2evxgw.

\section{Notes to Chapter 5}

I Among other activities, CEDECA monitors adolescents from the neighbourhood in their compliance with 'socio-educational measures' in open areas (Assisted Liberty and Community Service, according to the Child and Adolescent Statute). These measures apply to individuals sent there by the judiciary upon being charged with committing an offence.

2 Translator's note: A cavaquinho is a very small stringed instrument used to play samba, similar to a ukulele.

3 In Feltran (2010b) I study the regulating of the 'world of crime', from the 


\section{Notes}

assassins typical of ig8os São Paulo, to the present scenario of arbitration via 'debates'.

4 Machado da Silva (I999) identified the legitimate coexistence of two orderings with other contents in Rio de Janeiro's favelas, with his argument retrieved and debated in Misse (2006a).

5 The police officer informed Ricardo of the name of his division; however, I have omitted any references in this chapter that would identify police officers, divisions and police stations, also using fictional names and changing street and favela names, in order to preserve the interlocutors' anonymity.

6 On the Portuguese expression 'dar um psicológico' ('to use psychology') and its meanings in context, see the analysis by Marques A.J. (2007, 2010).

7 'Idea' is practically synonymous with conversation, making 'exchanging ideas' conversing and 'giving ideas' giving advice or speaking with someone, opening up the possibility of dialogue. According to Ricardo, the police officer enquired as to the possibility of 'conversing' about the boys' situation, opening up the possibility of a financial agreement. See Zaluar (1985).

8 I have been studying Ivete's family for years (Feltran, 2007, 2008, 2009).

9 The news wasn't easy for me to digest; perhaps of all the stories I had followed in Sapopemba that of Marcela is the one to have created the greatest personal impression on me. I discuss her trajectory in Feltran (2007).

Io I have briefly reflected on the transference of 'crime' to the body of the criminal, and then to those who are similar to him/her, in Feltran (2008). Misse deals with this phenomenon - conceived of as criminal subjectification - in Misse (2010).

I I Zaluar and Ribeiro (2009) reflect and theorise more specifically on the paradox of close neighbourly relations in areas with high rates of violence in Rio de Janeiro.

I2 This is the term given to assaults on individuals who make substantial withdrawals in bank agencies or from ATMs. One person stays inside the bank observing and passing information to another person outside, who follows the customer and approaches them when the opportunity strikes.

I3 Fernando used the following three categories: Comando (Command), which would have been the expression used by the police, then PCG and then Partido (Party). The police wouldn't have used the common expression 'brothers'.

I4 A military police officer once told me in an informal conversation that in the fifteen minutes between arresting a dealer and escorting him to the nearest police station, he received no less than three calls from lawyers and police officers, asking about what had happened and informing him of 'who he was dealing with'. 


\section{Notes}

I5 The family has four cars, with three stolen and Neto's being paid for in instalments.

I6 A month later, a newspaper in wide circulation reported on a corruption scandal involving stolen cars, bribes and money laundering using the patio of this same police station as a privileged territory.

I7 Although divine justice is the most abstract among these, its absolute superiority in relation to the others is enunciated very frequently, such as in these lyrics by São Paulo's leading hip-hop group, Racionais MC: 'the Prosecutor is only a man / God is the Judge'.

I8 In the rainy season, landslides that destroy homes are common on the favela hillsides. In such cases, residents' first port of call is a television network that has been there before. They do the same when attempting to prove paternity or for intervention in police cases etc.

I9 Das (2006a), especially chapter 9 .

20 See Foucault (200I, p. 227); an appropriation of his argument in contemporary Brazil is found in Telles (2009).

\section{Notes to Chapter 6}

I Expressions commonly used by both government and criminal actors are presented in italics. This acknowledges the argument made by Machado da Silva (I999) regarding the notion of urban violence, and discussed by Misse (2006a) with reference to the idea of public security, that these categories are not neutral tools of analysis but representations that are a significant part of the objects of analysis themselves.

2 As proposed by Boltanski and Thevenot (I99I) and Thevenot (2006). To offer one example, the governor updates the government matrix of justification when he declares that he 'does not bargain with a bandido', or that he 'dismantled the PCC'. But the PCC-affiliated kidnappers of a Rede Globo reporter did not mobilise a different but, rather, the same discourse of the government when they advocated the use of the Law of Penal Executions on a broadcast network. However, a different matrix - that of 'crime' - is mobilised to justify the death of someone in a PCC 'debate' (Marques, 2007; Hirata, 2018; Feltran, 2010a, 2010b; Kessler and Telles, 2010).

3 This analogy was at least evident in my fieldwork: Marcela told me in 2005 that 'the PCG is like the GOE [Special Operations Group] in prison'. Lázaro, her brother, told me also in 2005 that having the PCC in prison 'was the same as having the prison staff. It's also a form of discipline, the same form of discipline: they don't let fights or riots happen, they run things. [Can everyone be part of the chain of command?] Anyone, someone from another faction can't join. But aside from that everyone can join, because it's not a faction, anyone can join, everyone 


\section{Notes}

is respected. A guy will have the same respect for us as he has for his brother, who is in the Command.' About this symmetry between the PCC and government in the 'dominated prisons', see Mallart (2012).

4 As an ex-prison officer, recruited in 1998 at the peak of this intense restructuring process, recounted: 'there were five directors [per prison, who delivered the preparatory course for the officers]. (...) I stayed in this "school" for about forty days. It was where I had classes in Criminal Law, Criminology, we had an Ethics class, we had a Personal Defence class, we had a class in Penitentiary Security, with professors who later became the directors of the prison, and with professors from the Prison Administration Secretariat for the State of São Paulo. (...) The classes were interesting. One of the most interesting things was that the slogan of all teachers, including those who became directors, was rehabilitation. According to the new Penal Code (...) humanitarian treatment of prisoners was fundamental. (...) Violence was only to be used as a last resort.' (Paulo).

5 The same Paulo, who during the training course had been convinced by the rhetoric of rehabilitation, saw his hopes dashed after only three months in the new prison. 'Until then I had not seen any attitudes of violence among the directors. I had only seen them among older employees. Then I started to see it among the directors themselves. Those that talked about rehabilitation, and this happened on my shift, which was the night shift. Some prisoners arrived from the City Penitentiary [fictitious name]. There was trouble at that prison and they brought the leaders. They gave them a truck and took it to Municipality [fictitious name]. (...) The director called the head on duty, my friend, and said he wanted the biggest guys to receive the "bonde" [vehicle used to transport prisoners]. They called me, called several people, the highest ranking. They called Paulo, who later got the nickname Superman, who was an extremely violent guy. They called Pedro, who was a good guy, but later became violent. And then we went to an inclusion sector (...), we got there and the directors came. (...) The guys who worked up there brought a lot of clubs, we called it "lowering the pipe". They were water pipes, made of iron, and at the base there was a slightly larger pipe, made of PVC, and it was pierced, with a piece of string [tied in a loop, shows how they wrapped the handle], so it wouldn't fall. (...) He brought the pipes, each director took one. One of the directors brought a wooden club that looked like a baseball bat. (...) All of it was to welcome the arrivals. The director said, "Look, is there anyone who does want to participate?" I said, "I don't want to." (...) It's funny that the employees were anxious, isn't it? It's a mix, but I think there was a desire to give some beatings. That was the conclusion I came to later. The prisoners arrived and started to come down one by one, with heads down in their underwear. (...) I only heard 


\section{Notes}

the prisoners' screams: "Stop sir, it hurts! It hurts, sir! Stop, stop!" There were ten guards beating them, one by one, with the directors there. One by one.'

\section{NOTES TO CONCLUSION}

I The position occupied by the poor in Brazilian democracy and in Brazilian cities, as well as the relation between poverty, development and citizenship, has always been a central theme of the literature. It has been approached from a Marxist perspective (Kowarick, I987; Oliveira, I982), including within both Gramscian (Machado da Silva, I993; Dagnino, I994, 2002) and Thompsonian (Sader, I988; Telles and Paoli, I994) traditions, as well as more culturalist approaches (Caldeira, 2000; Durham, 1977) or with Arendtian (Telles, 200I) or Habermasian (Zaluar, 2004) influences.

2 An example of this is the prolific work of the Centro de Estudos de Metrópole, dedicated to gathering evidence, using methods ranging from demography to ethnography, to develop hypotheses and contribute to debates around a range of current arguments in the literature on themes such as inequality (Marques and Bichir, 2011), labour relations (Guimarães, N.A., 2009, 2012), urban territory and poverty (Marques and Bichir, 20II), social policies (Arretche, 2010), state strategies for governing the 'social' (Feltran, 20I I, 20I2; Marques, 2014) and race relations (Guimarães, A.S.A., 2012), among others.

3 In different ways, Telles and Cabanes (2006), Rizek and Oliveira (2006), Cabanes, Georges, Rizek and Telles (20I I) and Vieira and Feltran (20I3), as well as the work of NECVU-UFRJ (Núcleo de Estudos da Cidadania, Conflito e Violência Urbana-Universidade Federal do Rio de Janeiro [Centre for Studies of Citizenship, Conflict and Urban Violence-Federal University of Rio de Janeiro]), CEVIS-IESP/UERJ (Coletivo de Estudos sobre Violência e Sociabilidade-Instituto de Estudos Sociais e Políticos/ Universidade do Estado do Rio de Janeiro [Collective Studies about Violence and Sociability-Institute for Social and Political Studies/ State University of Rio de Janeiro]) and the Urban Ethnography Group (Núcleo de Etnografias Urbanas) at CEBRAP (Centro Brasileiro de Análise e Planejamento [Brazilian Center for Analysis and Planning]), especially Rui (2012), Fiore (2013) and Malvasi (2012), are example of this strand within the bibliography.

4 This reflection is inspired by analyses by Simmel (2014) and Arendt (200I) of how cultural objects are monetised. Monetisation must be preceded by work that makes the question 'how much does it cost?' plausible for objects for which it was previously unthinkable, as it would be today to ask 'how much does your child cost?' 


\section{Notes}

5 It is in this way symptomatic that the Municipal Secretary of Security, in personal conversations, has three times referred to the Public Security programme 'Crack, it is possible to win' (Crack, é possível vencer) as a 'fantasy name'. Public programmes have long had slogans formulated by marketers, obeying the logic of fragmentation between market niches.

6 If the notion of 'social question' had become pronounced in French debates about the welfare state (Ewald, I986), the contradictions between political and economic modernity (Telles and Paoli, I994) have led us to a critical, although paradoxical, horizon, in the sense that it is presumed that the problems arising from modernity must be overcome within the framework of modern teleology itself, through the creation and progressive extension of citizenship rights. Citizenship would thus be a measure of social relations (Telles, I994).

7 It is not, for example, the aesthetics of the worker that, at present, dictate the criteria of belonging to the social world among the younger generation in the peripheries; forms of aesthetic expression that have become widespread there in recent decades, such as rap or funk, show a division of sensibility (Rancière, I995) centred on a more radical alterity than in the past (Bertelli, 2014; Feltran, 2013b; Takahashi, 2014).

8 The prevailing logic of coalition governments at the national level since Brazil's 'democratic transition', the synthesis of the coexistence of Sarney and the MST, financial capital and the solidarity economy, environmentalists and agribusiness, the third sector and evangelicals, for example, favours the type of schizophrenia - in a theoretical sense - characteristic of these social (but also environmental, political and economic) actions. It seems that it is within this framework that contemporary government can be best understood.

9 This section synthesises and develops arguments previously made in Feltran (2013b; 20I4).

Io 'Thus, our relations develop on the basis of mutual knowledge, and this knowledge on the basis of the real relation, as two indissociably intertwined elements which, through their alternation within interaction, makes it seem like one of the points in which being and representation make their mysterious unity empirically perceptible' (Simmel, 2oroa, pp. 30-3I).

I I Michel Foucault (I997) argues that the dispositif of modern sexuality is not primarily concerned with suppressing sex in a non-specific way; hence the profusion of modern discourses that, on the contrary, even today instigate it, from Sunday afternoons to Saturday nights. It was of more interest to legitimise an authority - sovereign, disciplinary, governmental - from which one could legitimately classify sexuality: to describe it, categorise it, hierarchise it. The modern administration of sex would benefit from this operation of capture and reification inscribed 


\section{Notes}

in the act of naming, also the act of moralising. The meaning of names would become routine as part of nature; would normalise the kind of sex that could plausibly be integrated into family and productive life, distinguishing it from the one to be banished from the dominant moral code, within the limits of legality. From the dark rooms of family patriarchs to the most abject slaves, the dispositif of sexuality would act by classifying, in order to rule.

I2 Not only 'evangelical thieves' or the 'settling of accounts between police and criminals', but hybrids between religious and criminal norms, for example (Marques, 2012). Hybridisms between different regimes are, in practice, constant in the peripheries - religious syncretism, the fusion of political ideologies etc. Liberation theology, associating historical materialism and Christianity, for example, was extremely successful for at least two decades in Brazil.

I3 Samuel's real name, as well as parts of his trajectory, have been withheld so as to protect his identity. I had contact with him during my field research between 2005 and 2018 . 